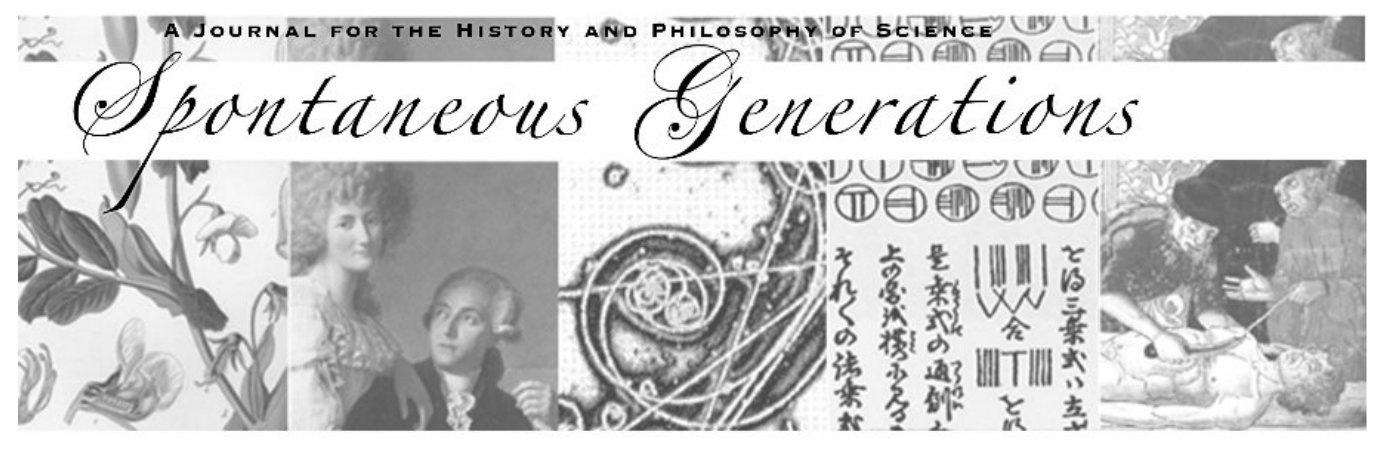

\title{
Apparatus and Experimentation Revisited
}

Author(s): Trevor H. Levere

Source: Spontaneous Generations: A Journal for the History and Philosophy of Science, Vol. 4, No. 1 (2010) 148-154.

Published by: The University of Toronto

DOI: $10.4245 /$ sponge.v4i1.11892

EDITORIAL OFFICES

Institute for the History and Philosophy of Science and Technology Room 316 Victoria College, 91 Charles Street West

Toronto, Ontario, Canada M5S 1K7

hapsat.society@utoronto.ca

Published online at jps.library.utoronto.ca/index.php/SpontaneousGenerations ISSN 19130465

Founded in 2006, Spontaneous Generations is an online academic journal published by graduate students at the Institute for the History and Philosophy of Science and Technology, University of Toronto. There is no subscription or membership fee. Spontaneous Generations provides immediate open access to its content on the principle that making research freely available to the public supports a greater global exchange of knowledge. 


\title{
Apparatus and Experimentation Revisited*
}

\author{
Trevor H. Levere ${ }^{\dagger}$
}

\begin{abstract}
Those with knowledge about scientific instruments come from many different fields. Prominent among them are (1) collectors and dealers, (2) curators, (3) historians, (4) instrument makers, (5) philosophers, and (6) scientists (the order is alphabetical, not value-laden). The annual symposium of the Scientific Instrument Commission often brings members of each of these groups together, and they learn from one another. What follows are brief reflections on the activities of each group when its members consider instruments.
\end{abstract}

\section{Collectors and DeAlers}

Collectors and dealers, whose interest is often antiquarian and financial, need to be knowledgeable, since lot of money may be involved. As an extreme case, in 1995 Christie's sold at auction an astrolabe made around 1590 by Erasmus Habermel, astronomical and geometrical instrument maker to the Holy Roman Emperor Rudolf II. The sale price was $£ 540,500$ (New York Times, 14 October 1995). It takes serious scholarship to identify, date, and authenticate a previously unknown instrument to the point where purchasers can be confident that what they are buying is genuine; fakes abound. A good eye, the kind of visual memory that is important for an archaeologist, and the ability to conduct an examination of related instruments that can reveal such details as the gradually deteriorating engraving tools of particular craftsmen are all germane, as is familiarity with archival research; sometimes these skills are supported by laboratory tests, including $X$-ray analysis (transmission X-ray diffraction, X-ray fluorescence, and X-ray radiography) (Turner 1994; 2000; Newbury et al. 2006). The attention to detail is important for historians and for antiquarians alike. It may mean that categories used

* Received 21 February 2010.

$\dagger$ I have worked extensively on the history of chemistry and almost as extensively on the history of scientific instruments, with an emphasis on the eighteenth and nineteenth centuries. Other interests include Arctic science, Canadian science, and science and Romanticism. I have written monographs and numerous papers in each of these areas; newcomers to the history of chemistry may find it useful to look at my Transforming Matter: A History of Chemistry from Alchemy to the Buckyball (Johns Hopkins University Press, 2001). 
by some historians are judged by collectors to obscure rather than reveal insight. Antiquarians, collectors, and dealers have no time for black-boxing, since even when an instrument is accepted and used unquestioningly in the laboratory, instrument makers focus on refinement and innovation, since that is what originally led people buy their work. It is this refinement and innovation that interests collectors today. For example, the second half of the eighteenth century saw a dramatic increase in the development of precision in the making of philosophical and mathematical instruments (Wise 1995). Collectors and natural philosophers (the word "scientist" was not coined until 1834) competed for the products of the most precise instrument makers of the day. Jesse Ramsden, whose dividing engine was unequalled, had a waiting list that included royalty and scientists with money (McConnell 2007; Morton and West 1993). The rate at which precision advanced is astonishing. The balances described and illustrated in the Encyclopédie of Diderot and d'Alembert are crude. In the mid-eighteenth century, contemporaneously with the publication of the Encyclopédie, Joseph Black used a balance that could weigh accurately to about one part in 200. Well before the end of the century, the best balances (for example, the one made by John Harrison for Cavendish in England and that made by Fortin for Lavoisier in France) could weigh to one part in 400,000 (Stock 1969).

It is worth pausing to ask how the latter instruments were used. Lavoisier stressed the importance of a precise balance in the chemical laboratory, but his gravimetric results were sometimes in error by about one part in five. The balance was 80,000 times better than Lavoisier's worst results. Clearly, there is a difference between accuracy and precision. The accuracy of a result is limited by accumulated errors, and, like a chain, it cannot be stronger than its weakest link. Instrument makers and scientists shared a drive for ever greater precision, but, at least in chemistry, the means to translate that into greater accuracy were poorly understood; the drive for ever greater precision stems frequently from the perfectionism of instrument makers, which may far outstrip the needs of the scientist (Levere 2010).

\section{CuRATORS}

Curators in science museums maintain collections, acquire new instruments, and produce catalogues of their collections, often with contextual and interpretive essays (fine examples include: Anderson 1948; Brenni 1995; da Conceição Ruivo 1997; Morton and Wess 1993; Rambaldi 1996; Turner 1996). Some produce a catalogue raisonnée of the work of a single instrument maker (e.g. Pantalony 2009). Many of them do a lot more than this, but for my purposes these are key activities. Museum 
collections can be used as research tools for extending our understanding of the practice of science, and for complementary research that involves the recreation of historic scientific experiments. Recent publications, some of the best by curators, exemplify such usage (Pantalony 2005 and 2009; Usselman et al. 2005; Morrison-Low 2007). There is a great deal to be learned from these studies, and indeed there are research programs devoted to experimental recreations. Sometimes the results are frustrating: Coulomb's torsion experiment, for example, seems impossible to recreate, but there is little doubt that Coulomb did what he claimed (Blondel et al. 1994; Martínez 2006).

\section{HISTORIANS}

Historians of science and of society used often to ignore the work of curators and seldom moved beyond the library to the museum and the laboratory. In many ways, that was a legacy from the decades when the history of science was essentially the history of ideas, as in the work of Alexandre Koyre. But that has changed, and is still changing. The work of Maurice Daumas, focusing on instruments, was an early instance (Daumas 1953; 1972). Galison (1987) and Trenn (1992) looked at the practice of science, including the use of apparatus. Stillman Drake reconstructed Galileo's experiments, largely from his manuscripts, but with careful attention to surviving instruments (Drake 1978). And John Heilbron, who has valued the study of instruments for what they can tell us about science, wrote a remarkable book about cathedrals as solar observatories (1999). There is a substantial literature about public lectures and demonstrations and the ways in which they used instruments (among the best studies of this kind are Golinski 1992; Stewart 1992).

An interest in chemical apparatus often depends on documentary evidence, since surviving chemical apparatus is scarcely representative of the range used. Glass and earthenware both break easily, unlike wood and brass; Lavoisier's laboratory had many hundreds of pieces of glassware, and few of these have survived. Chemical apparatus was often modular, and, in the days before the mass production of ground glass stoppers and the availability of rubber tubing, individual parts of an apparatus were joined together with lutes; these were hard if not impossible to separate after use in an experiment, and so they were often discarded. It is not surprising that the small fraction of glassware that remains from Lavoisier's laboratory consists mostly of vessels with brass attachments, so that they can be connected or separated with ease. Lavoisier's apparatus was made with skill, as one can see from his apparatus in the Musée des arts et métiers; we can see how much cruder and less reliable was the apparatus made for Black in Edinburgh and for Proust in Segovia, because some of it 
survives; we would otherwise have no way of understanding the practical problems posed by inadequate glassware made by local bottle factories (Holmes and Levere 2000). The changes in chemistry have been reflected in an increasing awareness of the role of instruments; a conference and subsequent book on the history of twentieth-century chemistry dealt with "The Instrumental Revolution" (Morris 2002).

\section{INSTRUMENT MAKERS}

In spite of the fact that much scientific apparatus is electronic and modular, much still requires traditional skills. Glassblowers are still important in modern chemical laboratories, and craftsmen still make historic apparatus for public demonstrations and for museums. The Steno Museum of Aarhus University combines historic apparatus with modern reconstructions of such apparatus; there is a lot to be learned about the practice of science from such reconstructions. Brundtland's study of the air pump was informed by his skill as an instrument maker (Brundtland 2008). Brenni is in demand for the conservation and also the restoration of historic instruments. More generally, the demonstrators in science departments frequently have old instruments in their care, and are knowledgeable about the use of these instruments.

\section{PHILOSOPHERS}

The epistemology of science is in part dependent upon instruments. Baird has written more extensively than most about the ways in which instruments and apparatus embody knowledge. The epigraph to Baird 2004 begins with the statement that "the history of physical science is largely the history of instruments and their intelligent use." Hacking (1992) has drawn attention to the self-validation of scientific instruments; an instrument designed to show something anticipated within a theoretical framework is likely to reinforce that framework. These are important and useful perceptions. But it is worth noting that sometimes the phenomenon that Stephen Jay Gould encapsulated in the phrase "the panda's thumb" turns up in the development of instruments. Hales is generally identified as the inventor of the pneumatic trough, and in a sense he was, but he intended that device to serve simply as a washing bottle, to clean air of soluble impurities. Pneumatic chemistry was not yet a science, although Hales's invention would contribute to it significantly (Crosland 2000).

\section{SCIENTISTS}

The history of science sometimes becomes an avocation for retired scientists, but some of the greatest scientists have had a keen awareness 
of the work of their predecessors. Isaac Newton's remark about standing on the shoulders of giants may have been intended to irritate the unusually short Robert Hooke, but it was surely also meant to be taken seriously. Einstein wrote a foreword to Drake's translation of Galileo's Two Chief World Systems (Galileo 1953). Lavoisier's Opuscules (Lavoisier 1774) is, unlike his later work, thoroughly respectful of his predecessors. In his Traite (Lavoisier 1789), he wrote that his work would have been much more readily understood had he devoted more space to the description and use of apparatus, which now occupied one third of his book. But it took a modern chemist, Donald Cotter, to point out to me what should have been obvious to every modern historian: Lavoisier insisted on the importance of the precision balance for research, but did not spend space or time explaining how the laboratory chemist should ensure that the balance was in good order, nor did he perform the operations that would have made sure of this. That has some bearing on the reliability of his results. We cannot and should not try to apply the standards of modern laboratory science to older experimental research, but an awareness of those standards can help us understand the ways in which historic apparatus was used. It is crucial to enlist today's scientists in conserving the material heritage of science embodied in scientific instruments.

\author{
TREVOR H. LEVERE \\ IHPST, University of Toronto \\ 316 Victoria College \\ 91 Charles Street West \\ Toronto, Ontario M5S 1K7 \\ trevor.levere@utoronto.ca
}

\title{
REFERENCES
}

Baird, Davis. 2004. Thing Knowledge: A Philosophy of Scientific Instruments. Berkeley: University of California Press.

Blondel, Christine, Matthias Dörries, Dominique Pestre, Bruno Belhoste, Peter Heering, Christian Licoppe, Lucio Fregonese, and John Lewis Heilbron. 1994. Restaging Coulomb: usages, controverses et replications autour de la balance de torsion. Firenze: L. S. Olschki.

Brenni, Paolo. 1995. Gli strumenti di fisica dell'Istituto Tecnico Toscano: Ottica (Fondazione Scienza e Tecnica). Firenze: Giunti.

Brundtland, Terje. 2008. From medicine to natural philosophy: Francis Hauksbee's way to the air pump. British Journal for the History of Science 41: 209-40. 
Crosland, Maurice. 2000. Slippery Substances. In Instruments and Experimentation in the History of Chemistry, eds. Frederic L. Holmes and Trevor Levere, 75-104. Cambridge, MA: MIT Press.

da Conceição Ruivo, Maria, ed. 1997. Ingenuity and Art: A collection of Instruments of the Real Gabinete de Física. Coimbra: Calouste Gulbenkian Foundation.

Daumas, Maruice. 1953. Les instruments scientifiques aux xvii et xviii siècles. Paris: Presses Universitaires de France.

Daumas, Maurice. 1972. Scientific Instruments of the Seventeenth and Eighteenth Centuries. Ed. and trans. Mary Holbrook. New York: Praeger Publishers.

Drake, Stillman. 1975. Galileo at Work: His Scientific Biography. Chicago: University of Chicago Press.

Galileo Galilei. 1953. Two Chief World Systems. Trans. Stillman Drake. Berkeley: University of California Press.

Galison, Peter. 1987. How Experiments End. Chicago: University of Chicago Press.

Golinski, Jan. 1992. Science as Public Culture: Chemistry and Enlightenment in Britain, 1760-1820. Cambridge: Cambridge University Press.

Hacking, lan. 1992. The Self-Vindication of the Laboratory Science. In Science as Practice and Culture, ed. Andrew Pickering, 29-64. Chicago: University of Chicago Press.

Heilbron, John L. 1999. The Sun in the Church: Cathedrals as Solar Observatories. Cambridge, MA: Harvard University Press.

Holmes, Frederic L., and Trevor H. Levere. 2000. Instruments and Experimentation in the History of Chemistry. Cambridge, MA: MIT Press.

Lavoisier, Antoine-Laurent. 1774. Opuscules Physiques et Chimiques. Paris: Chez Durand neveu.

Lavoisier, Antoine-Laurent. 1789. Traité Élémentaire de Chimie, présenté dans un ordre nouveau et d'après les découvertes modernes. Paris: chez Cuchet.

Levere, Trevor Harvey. 2010. The 2009 Edelstein Address. Sons of Genius: Chemical Manipulation and Shifting Norms of Practice from Joseph Black to Michael Faraday. Bulletin of the American Chemical Society 35: 1-6.

Martínez, Alberto A. 2006. Replication of Coulomb's Torsion Balance Experiment. Archive for History of Exact Sciences 60: 517-63.

McConnell, Anita. 2007. Jesse Ramsden (1735-1800): London's Leading Scientific Instrument Maker. Aldershot, UK: Ashgate.

Morris, Peter J. T., ed. 2002. From Classical to Modern Chemistry: The Instrumental Revolution. London: Royal Society of Chemistry in association with the Science Museum and the Chemical Heritage Foundation.

Morrison-Low, Alison D. 2007. Making Scientific Instruments in the Industrial Revolution. Aldershot, UK: Ashgate. 
Morton, Alan Q., and Jane A. West. 1993. Public \& Private Science. Oxford: Oxford University Press.

Newbury, B.D., M.R. Notis, B. Stephenson, G. S. Cargill III, and G. B. Stephenson. 2006. The Astrolabe Craftsmen of Lahore and Early Brass Metallurgy. Annals of Science 63: 201-13.

Pantalony, David A. 2005. Rudolph Koenig's Workshop of Sound: Instruments, Theories, and the Debate over Combination Tones. Annals of Science 62:57-82.

Pantalony, David A. 2010. Altered Sensations: Rudolph Koenig's Acoustical Workshop in Nineteenth-Century Paris. Dordrecht: Springer.

Rambaldi, Gabriella. 1996. Istrumenti di Chimica: Un laboratorio del XIX secolo. Genova: Pirella.

Stewart, Larry. 1992. The Rise of Public Culture: Rhetoric, Technology, and Natural Philosophy in Newtonian Britain, 1660-1750. New York: Cambridge University Press.

Stock, John T. 1969. The Development of the Chemical Balance. London: HMSO.

Trenn, Thaddeus J. 1977. The Self-Splitting Atom: The History of the Rutherford-Soddy Collaboration. London: Taylor \& Francis.

Turner, Gerard L'Estrange. 1994. The three astrolabes of Gerard Mercator. Annals of Science 59: 329-53.

Turner, Gerard L'Estrange. 2000. Elizabethan Instrument Makers: The Origins of the London Trade in Precision Instrument Makers. Oxford: Oxford University Press.

Usselman, Melvyn C., Christina Reinhardt, Kelly Foulser, and Alan J. Rocke. 2005. Restaging Liebig: A Study in the Replication of Experiments. Annals of Science 62: 1-55.

Wise, M. Norton, ed. 1995. The Virtues of Precision. Princeton: Princeton University Press. 